Article

\title{
Design of an Affibody-Based Recognition Strategy for Human Epidermal Growth Factor Receptor 2 (HER2) Detection by Electrochemical Biosensors
}

\author{
Hoda Ilkhani, Andrea Ravalli and Giovanna Marrazza * \\ Department of Chemistry "Ugo Schiff”, University of Florence, Via della Lastruccia 3, \\ 50019 Sesto Fiorentino (FI), Italy; jeyranh@yahoo.com (H.I.); andrea.ravalli@unifi.it (A.R.) \\ * Correspondence: giovanna.marrazza@unifi.it; Tel.: +39-055-457-3320 \\ Academic Editors: Paolo Ugo and Ligia Moretto \\ Received: 26 July 2016; Accepted: 30 November 2016; Published: 2 December 2016
}

\begin{abstract}
In this study, we have designed and realized three simple electrochemical bioassays for the detection of the human epidermal growth factor receptor 2 (HER2) cancer biomarker using magnetic beads coupling screen-printed arrays. The different approaches were based on a sandwich format in which affibody ( $\mathrm{Af}$ ) or antibody $(\mathrm{Ab})$ molecules were coupled respectively to streptavidin or protein A-modified magnetic beads. The bioreceptor-modified beads were used to capture the HER2 protein from the sample and sandwich assay was performed by adding the labeled secondary affibody or the antibody. An enzyme-amplified detection scheme based on the coupling of secondary biotinylated bioreceptor with streptavidin-alkaline phosphatase enzyme conjugate was then applied. The enzyme catalyzed the hydrolysis of the electro-inactive 1-naphthyl-phosphate to the electro-active 1-naphthol, which was detected by means of differential pulse voltammetry (DPV). Each developed assay has been studied and optimized. Furthermore, a thorough comparison of the analytical performances of developed assays was performed. Finally, preliminary experiments using serum samples spiked with HER2 protein were also carried out.
\end{abstract}

Keywords: affibody; immunosensor; magnetic beads; electrochemical detection; cancer biomarker

\section{Introduction}

One of the biggest factors associated with successful treatment outcome is the early detection of cancer [1]. Unfortunately, for many types of cancers, the first outward symptoms appear late in disease progression; therefore, cancer biomarker detection in biological fluids including serum, sputum and urine has an important role in early cancer detection [2,3]. The human epidermal growth factor receptor 2 (HER2) protein is a member of the epidermal growth factor receptor (EGFR or ErbB) family and is a trans-membrane tyrosine kinase receptor [4]. The level of HER2 in serum has a direct relationship with the risk of diseases such as ovarian, lung, gastric and oral cancers [5,6]. The extracellular domain (ECD) of cleaved HER2 protein enters into the serum, serving as an indicator of increased HER2 expression [4,7]. The HER2 concentration in the serum of breast cancer patients is $15-75 \mathrm{ng} / \mathrm{mL}$, which is elevated when compared to that of normal individuals $(2-15 \mathrm{ng} / \mathrm{mL})$ [8]. Monitoring the level of HER2 protein could also be a good indicator of antitumor treatment efficiency [9]. Fluorescence in situ hybridization (FISH) and immunohistochemistry (IHC) are the most commonly used methods for HER2 analysis. Both procedures are complex, involve time-consuming steps and require specially trained personnel to carry them out. Therefore, several new methods are reported for HER2 detection in biological fluids [10-13].

Immunosensors are important analytical tools designed to detect the binding event between the antibody and antigen without the need for separation and washing steps [4]. The most common types 
of immunosensors are found in electrochemical [7,14-21], optical [22,23], and gravimetric [24] sensors. It is well known that electrochemical detection methods have been able to sensitively and quickly detect biomolecule targets with high selectivity [25-27].

Recently, instead of antibodies (Abs), affibodies (Afs) have been used as new bioreceptors in novel immunosensors for improving the selectivity and sensitivity of the assay $[28,29]$. Affibody molecules are engineered small proteins with 58 amino acid residues $(\approx 7 \mathrm{kDa})$ based on a single polypeptide and 3 R-helical bundle structure (the smallest and fastest known cooperatively folding structural domain), as derived from one of the Immunoglobulin G (IgG) binding domains of Staphylococcal protein A [30]. They have high affinity and selectivity for a wide variety of applications such as detection reagents [31] and inhibit receptor interactions [32].

Recently, there has been a focus on how apply the magnetic beads (MBs) coated with proteins, polymers or other molecules in different fields of biochemical science [33,34]. The protein-coated MBs have shown a variety of applications in immunosensors because of their high, specific affinity to biomolecules, possibility for solution-phase bio-recognition reaction, and easy washing and collection $[35,36]$. The protein A-coated magnetic beads can be used to immuno-precipitate target proteins from crude cell lysates using selected primary Abs. In addition, specific Abs can be chemically cross-linked to the protein A-coated surface to create reusable immuno-precipitation beads, thus avoiding the co-elution of antibodies with target antigens [37]. The streptavidin-coated magnetic beads (Strept-MBs) provide a fast and convenient method for manual or automated immuno-precipitation, protein interaction studies, DNA-protein pull downs and the purification of biotinylated proteins and nucleic acids. They use a recombinant form of streptavidin with a mass of $53 \mathrm{kDa}$ and a neutral isoelectric point [38]. Streptavidin is covalently coupled to the surface of the MBs. For each streptavidin molecule on the bead surface, there are four biotin-binding available sites. Unlike avidin, streptavidin has no carbohydrate groups, resulting in low nonspecific binding. Furthermore, the MBs exhibit low nonspecific binding in the presence of complex biological samples such as blood serum and whole cells [39].

In this study, different protocols using antibody $(\mathrm{Ab})$ and affibody $(\mathrm{Af})$ as capture and signaling bioreceptor were applied to disposable electrochemical immunosensors based on the sandwich assay for HER2 detection. The first protocol relies on immobilization of the antibody on the magnetic beads coated with protein A (Prot A-MBs) as capture bioreceptor and the use of the biotinylated affibody as a signaling bioreceptor. The second protocol relies of the use of biotinylated affibody as a capture bioreceptor and biotinylated antibody as a signaling bioreceptor. The last protocol relies on immobilization of the biotinylated affibody on the magnetic beads coated with streptavidin (Strept-MBs) as capture bioreceptors and the use of secondary biotinylated affibody as signaling bioreceptor as well. An enzyme-amplified detection scheme based on the coupling of secondary biotinylated bioreceptors with streptavidin-alkaline phosphatase conjugates was then applied. The enzyme catalyzed the hydrolysis of the electroinactive 1-naphthyl-phosphate to 1-naphthol; this product is electroactive and is detected by means of differential pulse voltammetry (DPV). Moreover, we have evaluated potential application of the bioassays for serum sample analysis. In all approaches, eight screen-printed electrochemical cells are used as transducers.

\section{Materials and Methods}

\subsection{Chemicals and Reagents}

Dynabeads ${ }^{\circledR}$ paramagnetic beads, coated with protein A (ProtA-MBs) and with streptavidin (Strept-MBs) were provided by Invitrogen (Milan, Italy). The monoclonal anti-human HER2 antibody (Ab1), the biotinylated anti-human HER2 antibody (Biot-Ab2) and the HER2 protein (R\&D Systems) were obtained from Space SRL (Milan, Italy). Biotinylated anti-HER2 affibody molecules were purchased from Abcam (Cambridge, UK). Sodium phosphate dibasic dihydrate and sodium phosphate monobasic monohydrate were purchased from Merck (Milan, Italy). Sodium chloride, Trizma base, 
diethanolamine, magnesium chloride, potassium chloride, polyoxyethylene sorbitan monolaurate (Tween 20), 1-naphtyl phosphate, bovine serum albumin (BSA), streptavidin-alkaline phosphatase (S-AP) and human serum sample were obtained from Sigma (Milan, Italy). All solutions were prepared using water from a Milli-Q Water Purification System (Millipore, UK).

All the buffers used in this study are as follows:

- Buffer A: phosphate-buffered saline (PBS, $0.10 \mathrm{M}, \mathrm{pH}=5.0$ ), containing $140 \mathrm{mM} \mathrm{NaCl}$ (with and without $0.05 \%$ Tween 20 );

- Buffer B: phosphate-buffered saline (PBS, $0.10 \mathrm{M}, \mathrm{pH}=7.4$ ), containing $0.10 \mathrm{M} \mathrm{KCl}$ (with and without $0.05 \%$ Tween 20 );

- Buffer C: diethanolamine buffer (DEA, $0.10 \mathrm{M}, \mathrm{pH}=9.6$ ), containing $1.0 \mathrm{mM} \mathrm{MgCl}_{2}$ and $100 \mathrm{mM}$ $\mathrm{KCl}$ (with and without $0.05 \%$ Tween 20 and $0.1 \% \mathrm{BSA}$ );

- Buffer D: Tris buffer (20 mM, pH = 7.4), containing $150 \mathrm{mM} \mathrm{NaCl}$ (with and without $0.05 \%$ Tween 20).

\subsection{Apparatus}

Electrochemical measurements were performed using Palmsens Electrochemical Interface system (Palm Instruments BV, Houten, The Netherlands). The transducer was composed of eight screen-printed electrochemical cells, each one composed of a graphite working electrode (diameter $=2.0 \mathrm{~mm}$ ), a silver pseudo-reference electrode and a graphite counter electrode. The arrays were produced in house by a DEK 248 screen-printing machine (DEK, Weymouth, UK). In order to use sensor array in combination with the magnetic beads, each array was placed on a suitable holding block mounting eight magnet bars of $1.5 \mathrm{~mm}$ diameter. The eight sensors strips, coupled with a specially designed methacrylate well box, were compatible with a standard 8-channel multi pipette. A sample mixer with a 12-tube mixing wheel and the magnet rack were purchased from Dynal Biotech (Milan, Italy).

\subsection{Development of Affibody-Based Assay}

The schematic representation of dual affibody sandwich assay for HER2 detection is reported in Scheme 1.

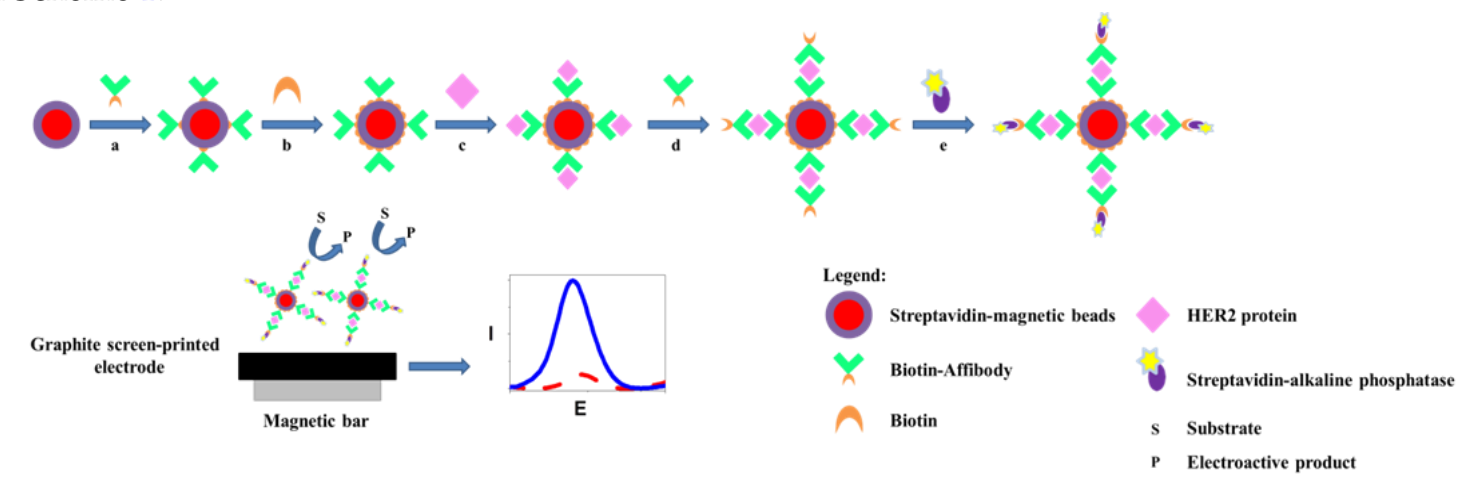

Scheme 1. Schematic representation affibody-based assay for human epidermal growth factor receptor 2 (HER2) detection: (a) functionalization of streptavidin-modified magnetic beads with the biotinylated affibody; (b) blocking step with biotin; (c) affinity reaction with HER2 protein; (d) incubation with the secondary biotinylated affibody; (e) addition of streptavidin-alkaline phosphatase enzyme. Electrochemical measurements were then performed in accordance with Section 2.3.5.

\subsubsection{Immobilization of the Biotinylated Affibody}

The streptavidin-modified magnetic beads (Strept-MB) were firstly washed with buffer A (added with $0.005 \%$ Tween 20 ) three times and, after the removal of the supernatant with the help of a magnetic rack, re-suspended in $100 \mu \mathrm{L}$ of buffer A added with Tween 20 . Then, $400 \mu \mathrm{L}$ of $5 \mu \mathrm{g} / \mathrm{mL}$ 
of the biotinylated affibody (Biot-Af) in buffer A was added to the beads suspension and left to incubate overnight.

\subsubsection{Blocking Step}

The affibody-modified beads (Strept-MB/Af) were washed and streptavidin free-sites were blocked by the addition of $1 \mathrm{mM}$ biotin (prepared in buffer B containing 1\% w/v BSA) for $90 \mathrm{~min}$. After three washing steps in buffer D (containing Tween 20), the beads were stocked in buffer $D$ at $4{ }^{\circ} \mathrm{C}$ for at least one week.

\subsubsection{Reaction with HER2 Protein}

To perform the calibration curve, $50 \mu \mathrm{L}$ of the modified beads were incubated with $200 \mu \mathrm{L}$ of HER2 protein at different concentrations prepared in buffer $\mathrm{D}$ for $20 \mathrm{~min}$ at room temperature. Three washing steps in buffer B-added Tween 20 were then performed.

In order to evaluate the selectivity of the developed assays, 5, 10 and $20 \mathrm{ng} / \mathrm{mL}$ of vascular endothelial growth factor (VEGF) protein, prepared in buffer D, were incubated instead of HER2 with the modified beads.

\subsubsection{Binding with the Biotinylated Affibody and Streptavidin-Alkaline Phosphatase Enzyme}

Firstly, $250 \mu \mathrm{L}$ of $5 \mu \mathrm{g} / \mathrm{mL}$ biotinylated affibody, as signaling bioreceptor, prepared in buffer B were incubated with the HER2-modified beads for $45 \mathrm{~min}$ at room temperature. Subsequently, three washing steps in buffer $C$ added with Tween 20 were performed.

Finally, the beads were incubated with $500 \mu \mathrm{L}$ of streptavidin-alkaline phosphatase $(3.9 \mathrm{U} / \mathrm{mL})$ prepared in buffer $\mathrm{C}$ added with $0.1 \% \mathrm{w} / \mathrm{v}$ BSA for $10 \mathrm{~min}$ at room temperature, followed by three washing steps with buffer $C$ added with Tween 20 .

After the removal of the supernatant, the beads were re-suspended in $50 \mu \mathrm{L}$ of buffer $\mathrm{C}$.

\subsubsection{Electrochemical Measurements}

For the electrochemical measurements, $4 \mu \mathrm{L}$ of the MB suspension was placed onto each working electrode of the eight screen-printed electrochemical cells and fixed in position through the help of a home-made magnet-holding block. Each well of the arrays was then filled with $60 \mu \mathrm{L}$ of a solution containing $1 \mathrm{mg} / \mathrm{mL}$ of 1-naphthyl phosphate enzyme substrate prepared in buffer C.

After 6 min of incubation, DPV measurements were performed at room temperature using the following parameters: potential range from -0.05 to $0.6 \mathrm{~V}$, step potential $7 \mathrm{mV}$, modulation amplitude $70 \mathrm{mV}$, interval time of $0.1 \mathrm{~s}$. The current peak height was taken as the analytical signal.

Each measurement was repeated at least 10 times using different screen-printed arrays. Percentage Relative Standard Deviation (\%RSD) values were calculated as measure of inter-assay reproducibility.

\subsection{Development of Antibody/Affibody Based Assay}

The scheme of antibody / affibody-based bioassay is illustrated in the Supplementary Materials (Figure S6).

\subsubsection{Immobilization of the Antibody}

Firstly, the protein A-modified magnetic beads (ProtA-MB) were washed with buffer A (added with $0.005 \%$ Tween 20 ) three times and, after the removal of the supernatant with the help of a magnetic rack, re-suspended in $100 \mu \mathrm{L}$ of buffer A added with Tween 20. Then, $400 \mu \mathrm{L}$ of $50 \mu \mathrm{g} / \mathrm{mL}$ of the antibody $(\mathrm{Ab})$ in buffer A were added to the beads suspension and left to incubate for $45 \mathrm{~min}$. 


\subsubsection{Blocking Step}

Subsequently, the Ab1-modified beads (ProtA-MB/Ab) were washed and the protein A-free site blocking step was performed using the addition of $5 \% \mathrm{w} / \mathrm{v}$ casein prepared in buffer A for $30 \mathrm{~min}$. After three washing steps in buffer D (containing Tween 20), the beads were stocked in buffer D at $4{ }^{\circ} \mathrm{C}$ for at least one week.

2.4.3. Reaction with HER2 Protein and Biotinylated Affibody, Labeling with Streptavidin-Alkaline Phosphatase and Electrochemical Measurements

The following steps were carried out as reported in the previous sections. Reaction with HER2 protein and evaluation of non-specific interaction with VEGF were carried out in accordance with Section 2.3.3.

The reaction with biotinylated affibody and labeling with streptavidin-alkaline phosphatase were carried out in accordance with Section 2.3.4.

Electrochemical measurements were then performed as reported in Section 2.3.5.

\subsection{Development of Affibody/Antibody-Based Assay}

The scheme of antibody/affibody based bioassay is illustrated in supplementary information (Figure S7).

Streptavidin-modified magnetic beads were functionalized with the biotinylated affibody and blocked with biotin in accordance with Sections 2.3.1 and 2.3.2. Furthermore, HER2 affinity reaction and non-specific test with VEGF protein were performed in accordance with Section 2.3.3.

Binding with Biotinylated Antibody and Streptavidin-Alkaline Phosphatase Enzyme

Firstly, $250 \mu \mathrm{L}$ of $1 \mu \mathrm{g} / \mathrm{mL}$ secondary biotinylated antibody (Biot-Ab2), as signaling bioreceptor, prepared in buffer $B$, were incubated with the HER2-modified beads for $60 \mathrm{~min}$ at room temperature. Subsequently, three washing steps in buffer $C$ added with Tween 20 were performed.

Finally, the beads were incubated with $500 \mu \mathrm{L}$ of streptavidin-alkaline phosphatase enzyme $(3.9 \mathrm{U} / \mathrm{mL})$ prepared in buffer $\mathrm{C}$ added with $0.1 \% \mathrm{w} / \mathrm{v}$ BSA for $10 \mathrm{~min}$ at room temperature, followed by three washing steps with buffer $C$ added with Tween 20 .

Electrochemical measurements were then performed in accordance with Section 2.3.5.

\subsection{Analysis of Serum Samples}

The human serum samples were filtered (Filtropur S, diameter of filter pores $0.2 \mu \mathrm{M}$ ), diluted 1:2 with buffer D and spiked with HER2 protein solution (range of concentration $0-20 \mathrm{ng} / \mathrm{mL}$ ). Then, $50 \mu \mathrm{L}$ of the affibody-modified bead suspension was incubated with $200 \mu \mathrm{L}$ of HER2 serum samples and the experiments were carried out as reported in Sections 2.3.4 and 2.3.5.

\section{Results and Discussion}

As mentioned before, in this study, different protocols using antibody (Ab) and affibody (Af) as capture and signaling bioreceptors were both applied to disposable electrochemical immunosensors based on the sandwich assay for HER2 detection. To achieve the best conditions, key parameters that affect the read-out response of each assay were studied and optimized. The optimization parameters of the developed assays are reported in the Supplementary Materials. In the following section, the studies of affibody-based assay are focused on and reported.

\subsection{Optimization of Experimental Parameters}

The optimization of the experimental parameters in the case of dual affibody sandwich assay was performed in order to find the best conditions for HER2 binding and detection. The suitable experimental conditions were chosen in accordance with the current difference value $(\Delta \mathrm{I})$ obtained in 
the presence of $10 \mathrm{ng} / \mathrm{mL}$ HER2 $\left(\mathrm{I}_{\mathrm{HER} 2}\right)$ and the blank $\left(0 \mathrm{ng} / \mathrm{mL}\right.$ HER2, $\left.\mathrm{I}_{\text {Blank }}\right)$, and the percentage Relative Standard Deviation (\%RSD) values (Table 1).

Firstly, the concentration and the incubation time of the biotinylated affibody (Biot-Af) on the surface of the streptavidin-modified magnetic beads (Strept-MBs) were optimized (Table 1, assay step a). In particular, 1, 5 and $10 \mu \mathrm{g} / \mathrm{mL}$ of biotinylated-affibody solutions (prepared in buffer A) were incubated with the Strept-MB, followed by blocking step with biotin, affinity reaction with HER2 protein and incubation with secondary biotinylated affibody labeled with streptavidin-AP.

The Biot-Af concentration of $1.0 \mu \mathrm{g} / \mathrm{mL}$ was not sufficient to bind the HER2, while a similar current difference was observed using an affibody concentration of 5.0 and $10 \mu \mathrm{g} / \mathrm{mL}\left(\Delta \mathrm{I}_{\mathrm{Af} .} 5 \mu \mathrm{g} / \mathrm{mL}=3.3 \mu \mathrm{A}\right.$; $\Delta \mathrm{I}_{\text {Af. } 10 \mu \mathrm{g} / \mathrm{mL}}=3.2 \mu \mathrm{A}$ ). Thus, the concentration of Biot-Af of $5.0 \mu \mathrm{g} / \mathrm{mL}$ was selected for the further experiments.

Table 1. Experimental parameters optimization for affibody-based sandwich assay. Current difference $\left(\Delta \mathrm{I}=\mathrm{I}_{\mathrm{HER} 2}-\mathrm{I}_{\text {Blank }}\right)$ represents the difference between the current obtained using $10 \mathrm{ng} / \mathrm{mL}\left(\mathrm{I}_{\mathrm{HER} 2}\right)$ and $0 \mathrm{ng} / \mathrm{mL}\left(\mathrm{I}_{\text {Blank }}\right)$ HER2 buffered solutions. The letters of assay step column are in accordance with Scheme 1. Percentage Relative Standard Deviation (\%RSD) values were calculated using at least 10 measurements obtained by different screen-printed arrays.

\begin{tabular}{|c|c|c|c|c|}
\hline Assay Step & Parameter & & $\begin{array}{c}\text { Current Difference }(\mu A) \\
\left(\Delta I=I_{\text {HER2 }}-I_{\text {Blank }}\right)\end{array}$ & $\%$ RSD \\
\hline \multirow{6}{*}{ a } & \multirow{3}{*}{ Biot-Af concentration } & $1 \mu \mathrm{g} / \mathrm{mL}$ & 1.5 & 8 \\
\hline & & $5 \mu \mathrm{g} / \mathrm{mL}$ & 3.3 & 7 \\
\hline & & $10 \mu \mathrm{g} / \mathrm{mL}$ & 3.2 & 10 \\
\hline & \multirow{3}{*}{ Biot-Af incubation time } & $120 \mathrm{~min}$ & 1.7 & 7 \\
\hline & & $240 \mathrm{~min}$ & 2.0 & 10 \\
\hline & & o.n. & 3.3 & 7 \\
\hline \multirow{3}{*}{$\mathrm{b}$} & \multirow{3}{*}{ Biotin incubation time } & $30 \mathrm{~min}$ & 1.2 & 8 \\
\hline & & $60 \mathrm{~min}$ & 2.2 & 9 \\
\hline & & $90 \mathrm{~min}$ & 3.3 & 7 \\
\hline \multirow{3}{*}{ c } & \multirow{3}{*}{ HER2 incubation time } & $10 \mathrm{~min}$ & 1.3 & 6 \\
\hline & & $20 \mathrm{~min}$ & 3.3 & 7 \\
\hline & & $60 \mathrm{~min}$ & 3.0 & 9 \\
\hline \multirow{6}{*}{$\mathrm{d}$} & \multirow{3}{*}{ Biot-Af concentration } & $1 \mu \mathrm{g} / \mathrm{mL}$ & 1.2 & 8 \\
\hline & & $5 \mu \mathrm{g} / \mathrm{mL}$ & 3.3 & 7 \\
\hline & & $10 \mu \mathrm{g} / \mathrm{mL}$ & 3.5 & 10 \\
\hline & \multirow{3}{*}{ Biot-Af incubation time } & $30 \mathrm{~min}$ & 1.6 & 7 \\
\hline & & $45 \mathrm{~min}$ & 3.3 & 7 \\
\hline & & $60 \mathrm{~min}$ & 2.9 & 9 \\
\hline
\end{tabular}

Biot-Af: biotinylated affibody; o.n.: overnight.

The incubation time of the primary Biot-Af with the streptavidin was also evaluated. The Biot-Af was left to incubate for 120, $240 \mathrm{~min}$ and overnight (o.n.) with the Strept-MBs. The best incubation time was found to be overnight probably due to the complete coverage of the surface of magnetic beads which ensures a higher recognition of the target protein (Table 1, assay step a). After the functionalization of the Strept-MBs with the Biot-Af, the conjugates were blocked with various blocking agents $(1.0 \mathrm{mM}$ Biotin solution containing $1 \% \mathrm{w} / \mathrm{v}$ BSA, BSA $1 \%$ and milk powder $5 \%$ for different incubation times: 30, 60 and $90 \mathrm{~min}$ ). The best blocking step in terms of sensitivity and reproducibility $(n=10)$ was performed using $1 \mathrm{mM}$ biotin containing $1 \% \mathrm{w} / \mathrm{v}$ BSA for $90 \mathrm{~min}$ (in accordance with ref. [40]) as reported in Table 1, assay step b and in Supplementary Materials Section 1.

The incubation time of the affinity reaction with the HER2 protein was also optimized. As can be observed in Table 1 (assay step c), $10 \mathrm{~min}$ as incubation time seems insufficient to bind the whole amount of the protein, while similar values in current difference were obtained using 20 or $60 \mathrm{~min}$ 
$\left(\Delta \mathrm{I}_{45} \min .=3.3 \mu \mathrm{A} ; \Delta \mathrm{I}_{60}\right.$ min. $\left.=3.0 \mu \mathrm{A}\right)$. The best results, in terms of signal-to-noise ratio and reproducibility $(\%$ RSD $=7, n=10)$, were obtained for an incubation time of $20 \mathrm{~min}$ which was selected as optimal. Finally, the concentration and the incubation time of the Biot-Af, used as secondary biotinylated bioreceptor, was evaluated (Table 1, assay step d). Particularly, the current difference using a concentration of $5.0 \mu \mathrm{g} / \mathrm{mL}$ is considerably higher than that at $1.0 \mu \mathrm{g} / \mathrm{mL}$, whereas similar behavior was obtained using an affibody concentration of $10 \mu \mathrm{g} / \mathrm{mL}$. With respect to the Biot-Af incubation time, $45 \mathrm{~min}$ was found as optimal both in terms of current difference and of \%RD.

\subsection{Sensitivity and Reproducibility}

Using the optimized conditions, the calibration curves for the quantification of HER2 in the case of all assays were obtained (Figure 1A) and the related DPV scans were plotted in Figure 1B. A linear response in the range of HER2 0-20 ng/mL was obtained for affibody/affibody (Af/Af: $y=0.33 x$, coefficient of determination $\left.\left(R^{2}\right)=0.997\right)$, affibody/antibody (Af/Ab: $y=0.23 x, R^{2}=0.993$ ) and for antibody/affibody (Ab/Af: $y=0.21 x, \mathrm{R}^{2}=0.98$ ) sandwich assays with limit of detection (LOD), calculated as 3 times standard deviation of blank divided the slope of calibration curve $\left(3 S_{\text {Blank }} /\right.$ Slope) of $1.8,2.6$ and $3.4 \mathrm{ng} / \mathrm{mL}$ respectively. Reproducibility of the proposed assays were also evaluated using at least 10 measurements performed on different screen-printed arrays. Results showed a mean \%RSD value of 7 for Af/Af assay, 10 for Af/ Ab assay and 11 for Ab/Af assay. Taking in consideration both the LOD and the \%RSD, the Af/Af assay showed better performance in comparison with Af/Ab and $\mathrm{Ab} / \mathrm{Af}$ mixed sandwich assays (and also with respect to the previous dual antibody-based sandwich assay reported in literature [19]) for HER2 determination (whose cut-off in serum sample was set to $15 \mathrm{ng} / \mathrm{mL}$ ).

Furthermore, the selectivity of the developed assays was also verified using 5, 10 and $20 \mathrm{ng} / \mathrm{mL}$ of the vascular endothelial growth factor (VEGF) protein, involved in the metastatic process of breast cancer [41], as a nonspecific molecule. No significant variation respect to the signal of the blank was found, confirming the high specificity of the affibody bioreceptors for the detection of the HER2 cancer protein (Figure 1A, inset).

The affibody-based assay was thus selected to evaluate the possibility of detecting the HER2 protein in serum samples.
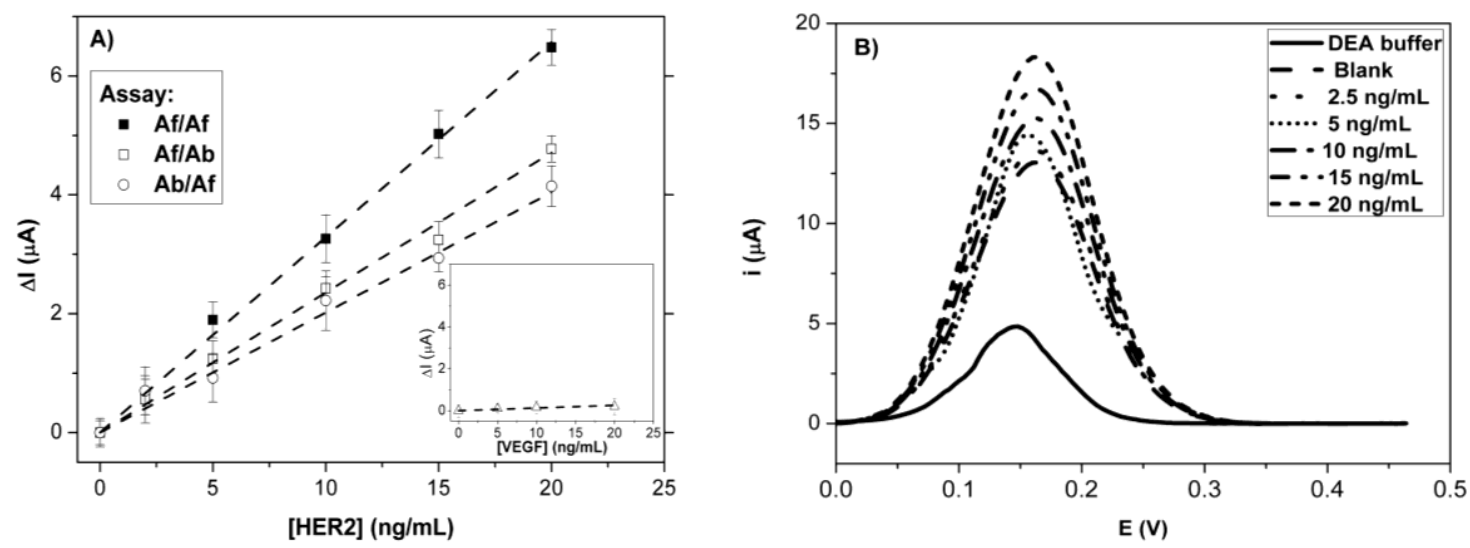

Figure 1. (A) Calibration curves for HER2 protein obtained using affibody/affibody (Af/Af), affibody/antibody (Af/Ab) and antibody/affibody (Ab/Af)-based assays. Inset: nonspecific interaction evaluation with vascular endothelial growth factor (VEGF) protein; (B) Differential pulse voltammetry (DPV) scans of Af/Af assay. Blank signal was subtracted from each measurement. Electrochemical measurements were performed in accordance with Section 2.3.5. Each measurement was repeated at least 10 times using different screen-printed sensors. 


\subsection{Analysis of Serum Samples}

Once the suitability of the dual affibody-based assay to detection of HER2 standard solutions was verified, experiments with HER2 fortified serum samples were carried. Batches of a non-pathologic serum AB group from females were filtered, diluted 1:2 in buffer D and spiked with HER2 protein in order to have four different final concentrations in the range of 5-20 ng/mL. Results are summarized in Table 2.

Table 2. Recovery, Bias and \%RSD for HER2 determination in fortified serum samples.

\begin{tabular}{ccccc}
\hline HER2 Spiked (ng/mL) & HER2 Found $(\mathbf{n g} / \mathbf{m L})$ & Recovery $\mathbf{( \% )}$ & Bias (\%) & \%RSD \\
\hline 5 & 5.5 & 110 & 10 & 12 \\
10 & 11 & 108 & 8 & 11 \\
15 & 15 & 97 & -3 & 14 \\
20 & 19 & 95 & -5 & 13 \\
\hline
\end{tabular}

Good recovery and difference between the average of measurements made on the same sample and its true value (bias values) (respectively in the range between $95 \%-110 \%$ and $-5 \%-10 \%$ ) were obtained. Furthermore, the mean \%RSD, calculated using at least 10 measurements obtained using different screen-printed arrays, was 13\%. These results confirm the suitability of the use of the proposed magnetic beads-based affibody assay for real sample analysis.

\section{Conclusions}

The potential of affibodies as bioreceptors in sandwich assay has been investigated by the optimization and the application of three strategies for the detection of HER2 protein. The best results were obtained by the use of affibody as both a capture and signaling bioreceptor. This biosensor showed the best sensitivity and detection limit and a good linear range in HER2-buffered solutions and serum samples. With this comparison, the importance of a deep study on the different analytical approaches for HER2 detection to obtain the performance of the best assay configurations has been demonstrated. Our results open up the way for the development of a new generation of biosensors for highly sensitive detection in a variety of analyses.

Supplementary Materials: The following are available online at www.mdpi.com/2227-9040/4/4/23/s1, Section 1: Response of graphite screen-printed arrays to the 1-naphthol; Section 2: Optimization of experimental parameters of affibody/affibody assay; Section 3: Optimization of experimental parameters of antibody/affibody assay; Section 4: Optimization of experimental parameters of affibody/antibody assay. Figure S1: Calibration curve of 1-naphthol; Figure S2: optimization of Af concentration as signaling bioreceptor; Figure S3: Optimization of the incubation time of the Af with HER2 as a signaling bioreceptor; Figure S4: Blocking agent optimization: BSA $1 \%(\mathrm{w} / \mathrm{v})$, dried milk powder $5 \%(\mathrm{w} / \mathrm{v})$ and IgG $10 \mathrm{mg} / \mathrm{mL}$; Figure S5: Incubation time optimization for dried milk powder 5\% (w/v) as blocking agent; Figure S6: Schematic representation of antibody/affibody-based assay for HER2 detection; Figure S7: Schematic representation of affibody/antibody assay for HER2 detection. Table S1: Experimental parameters optimization for antibody/affibody assay; Table S2: Experimental parameters optimization for affibody/antibody assay.

Author Contributions: Experiment details were conceived and designed by H.I. and G.M.; Data analysis was carried out by H.I., A.R. and G.M.; G.M. contributed reagents/materials/analysis tools; all contributors wrote the paper. Authorship must be limited to those who have contributed substantially to the work reported.

Conflicts of Interest: The authors declare no conflict of interest.

\section{References}

1. Ankerst, D.P.; Liss, M.; Zapata, D.; Hoefler, J.; Thompson, I.M.; Leach, R.J. A case control study of sarcosine as an early prostate cancer detection biomarker. BMC Urol. 2015, 15, 99. [CrossRef] [PubMed]

2. Payne, R.C.; Allard, J.W.; Anderson-Mauser, L.; Humphreys, J.D.; Tenney, D.Y.; Morris, D.L. Automated assay for HER-2/neu in serum. Clin. Chem. 2000, 46, 175-182. [PubMed]

3. Ravalli, A.; Marrazza, G. Gold and magnetic nanoparticles-based electrochemical biosensors for cancer biomarker determination. J. Nanosci. Nanotechnol. 2015, 15, 3307-3319. [CrossRef] [PubMed] 
4. Diaconu, I.; Cristea, C.; Hârceagă, V.; Marrazza, G.; Berindan-Neagoe, I.; Săndulescu, R. Electrochemical immunosensors in breast and ovarian cancer. Clin. Chim. Acta 2013, 425, 128-138. [CrossRef] [PubMed]

5. Slamon, D.J.; Godolphin, W.; Jones, L.A.; Holt, J.A.; Wong, S.G.; Keith, D.E.; Levin, W.J.; Stuart, S.G.; Udove, J.; Ullrich, A. Studies of the HER-2/neu proto-oncogene in human breast and ovarian cancer. Science 1989, 244, 707-712. [CrossRef] [PubMed]

6. Omenn, G.S.; Guan, Y.; Menon, R. A new class of protein cancer biomarker candidates: Differentially expressed splice variants of ERBB2 (HER2/neu) and ERBB1 (EGFR) in breast cancer cell lines. J. Proteom. 2014, 107, 103-112. [CrossRef] [PubMed]

7. Qureshi, A.; Gurbuz, Y.; Niazi, J.H. Label-free capacitance based aptasensor platform for the detection of HER2/ErbB2 cancer biomarker in serum. Sens. Actuators B Chem. 2015, 220, 1145-1151. [CrossRef]

8. Takahashi, Y.; Miyamoto, T.; Shiku, H.; Asano, R.; Yasukawa, T.; Kumagai, I.; Matsue, T. Electrochemical detection of epidermal growth factor receptors on a single living cell surface by scanning electrochemical microscopy. Anal. Chem. 2009, 81, 2785-2790. [CrossRef] [PubMed]

9. Patris, S.; De Pauw, P.; Vandeput, M.; Huet, J.; Van Antwerpen, P.; Muyldermans, S.; Kauffmann, J.M. Nanoimmunoassay onto a screen printed electrode for HER2 breast cancer biomarker determination. Talanta 2014, 130, 164-170. [CrossRef] [PubMed]

10. Arkan, E.; Saber, R.; Karimi, Z.; Shamsipur, M. A novel antibody-antigen based impedimetric immunosensor for low level detection of HER2 in serum samples of breast cancer patients via modification of a gold nanoparticles decorated multiwall carbon nanotube-ionic liquid electrode. Anal. Chim. Acta 2015, 874, 66-74. [CrossRef] [PubMed]

11. Engfeldt, T.; Orlova, A.; Tran, T.; Bruskin, A.; Widström, C.; Karlström, A.E.; Tolmachev, V. Imaging of HER2-expressing tumours using a synthetic Affibody molecule containing the 99mTc-chelating mercaptoacetyl-glycyl-glycyl-glycyl (MAG3) sequence. Eur. J. Nucl. Med. Mol. Imaging 2007, 34, 722-733. [CrossRef] [PubMed]

12. Emami, M.; Shamsipur, M.; Saber, R.; Irajirad, R. An electrochemical immunosensor for detection of a breast cancer biomarker based on antiHER2-iron oxide nanoparticle bioconjugates. Analyst 2014, 139, 2858-2866. [CrossRef] [PubMed]

13. Gohring, J.T.; Dale, P.S.; Fan, X. Detection of HER2 breast cancer biomarker using the opto-fluidic ring resonator biosensor. Sens. Actuators B Chem. 2010, 146, 226-230. [CrossRef]

14. Chen, H.; Tang, D.; Zhang, B.; Liu, B.; Cui, Y.; Chen, G. Electrochemical immunosensor for carcinoembryonic antigen based on nanosilver-coated magnetic beads and gold-graphene nanolabels. Talanta 2012, 91, 95-102. [CrossRef] [PubMed]

15. Zahmatkeshan, M.; Ilkhani, H.; Paknejad, M.; Adel, M.; Sarkar, S.; Saber, R. Analytical Characterization of Label-Free Immunosensor Subsystems Based on Multi-Walled Carbon Nanotube Array-Modified Gold Interface. Comb. Chem. High Throughput Screen. 2015, 18, 83-88. [CrossRef] [PubMed]

16. Ilkhani, H.; Sarparast, M.; Noori, A.; Zahra Bathaie, S.; Mousavi, M.F. Electrochemical aptamer/antibody based sandwich immunosensor for the detection of EGFR, a cancer biomarker, using gold nanoparticles as a signaling probe. Biosens. Bioelectron. 2015, 74, 491-497. [CrossRef] [PubMed]

17. Ravalli, A.; Pilon Dos Santos, G.; Ferroni, M.; Faglia, G.; Yamanaka, H.; Marrazza, G. New label free CA125 detection based on gold nanostructured screen-printed electrode. Sens. Actuators B Chem. 2013, 179, $194-200$. [CrossRef]

18. Taleat, Z.; Ravalli, A.; Mazloum-Ardakani, M.; Marrazza, G. CA125 Immunosensor Based on Poly-Anthranilic Acid Modified Screen-Printed Electrodes. Electroanalysis 2013, 25, 269-277. [CrossRef]

19. Al-Khafaji, Q.A.M.; Harris, M.; Tombelli, S.; Laschi, S.; Turner, A.P.F.; Mascini, M.; Marrazza, G. An Electrochemical Immunoassay for HER2 Detection. Electroanalysis 2012, 24, 735-742. [CrossRef]

20. Mucelli, S.P.; Zamuner, M.; Tormen, M.; Stanta, G.; Ugo, P. Nanoelectrode ensembles as recognition platform for electrochemical immunosensors. Biosens. Bioelectron. 2008, 23, 1900-1903. [CrossRef] [PubMed]

21. Eletxigerra, U.; Martinez-Perdiguero, J.; Merino, S.; Barderas, R.; Torrente-Rodríguez, R.M.; Villalonga, R.; Pingarrón, J.M.; Campuzano, S. Amperometric magnetoimmunosensor for ErbB2 breast cancer biomarker determination in human serum, cell lysates and intact breast cancer cells. Biosens. Bioelectron. 2015, 70, 34-41. [CrossRef] [PubMed]

22. Liu, X.; Liu, R.; Tang, Y.; Zhang, L.; Hou, X.; Lv, Y. Antibody-biotemplated HgS nanoparticles: Extremely sensitive labels for atomic fluorescence spectrometric immunoassay. Analyst 2012, 137, 1473. [CrossRef] [PubMed] 
23. Eletxigerra, U.; Martinez-Perdiguero, J.; Barderas, R.; Pingarrón, J.M.; Campuzano, S.; Merino, S. Surface plasmon resonance immunosensor for ErbB2 breast cancer biomarker determination in human serum and raw cancer cell lysates. Anal. Chim. Acta 2016, 905, 156-162. [CrossRef] [PubMed]

24. Miller, S.A.; Hiatt, L.A.; Keil, R.G.; Wright, D.W.; Cliffel, D.E. Multifunctional nanoparticles as simulants for a gravimetric immunoassay. Anal. Bioanal. Chem. 2011, 399, 1021-1029. [CrossRef] [PubMed]

25. Ilkhani, H.; Arvand, M.; Ganjali, M.R.; Marrazza, G.; Mascini, M. Nanostructured Screen Printed Graphite Electrode for the Development of a Novel Electrochemical Genosensor. Electroanalysis 2013, 25, 507-514. [CrossRef]

26. Xu, X.W.; Weng, X.H.; Wang, C.L.; Lin, W.W.; Liu, A.L.; Chen, W.; Lin, X.H. Detection EGFR exon 19 status of lung cancer patients by DNA electrochemical biosensor. Biosens. Bioelectron. 2016, 80, 411-417. [CrossRef] [PubMed]

27. Torati, S.R.; Reddy, V.; Yoon, S.S.; Kim, C. Electrochemical biosensor for Mycobacterium tuberculosis DNA detection based on gold nanotubes array electrode platform. Biosens. Bioelectron. 2016, 78, 483-488. [CrossRef] [PubMed]

28. Justino, C.I.L.; Freitas, A.C.; Pereira, R.; Duarte, A.C.; Rocha Santos, T.A.P. Recent developments in recognition elements for chemical sensors and biosensors. TrAC Trend. Anal. Chem. 2015, 68, 2-17. [CrossRef]

29. Ravalli, A.; da Rocha, C.G.; Yamanaka, H.; Marrazza, G. A label-free electrochemical affisensor for cancer marker detection: The case of HER2. Bioelecrochemistry 2015, 106, 268-275. [CrossRef] [PubMed]

30. Orlova, A.; Magnusson, M.; Eriksson, T.L.J.; Nilsson, M.; Larsson, B.; Höiden-Guthenberg, I.; Widström, C.; Carlsson, J.; Tolmachev, V.; Ståhl, S.; et al. Tumor imaging using a picomolar affinity HER2 binding Affibody molecule. Cancer Res. 2006, 66, 4339-4348. [CrossRef] [PubMed]

31. Hansson, M.; Ringdahl, J.; Robert, A.; Power, U.; Goetsch, L.; Nguyen, T.N.; Uhlén, M.; Ståhl, S.; Nygren, P. An in vitro selected binding protein (affibody) shows conformation-dependent recognition of the respiratory syncytial virus (RSV) G protein. Immunotechnology 1999, 4, 237-252. [CrossRef]

32. Ekerljung, L.; Lindborg, M.; Gedda, L.; Frejd, F.Y.; Carlsson, J.; Lennartsson, J. Dimeric HER2-specific affibody molecules inhibit proliferation of the SKBR-3 breast cancer cell line. Biochem. Biophys. Res. Commun. 2008, 377, 489-494. [CrossRef] [PubMed]

33. Samadi-Maybodi, A.; Nejad-Darzi, S.K.H.; Ilkhani, H. A new sensor for determination of paracetamol, phenylephrine hydrochloride and chlorpheniramine maleate in pharmaceutical samples using nickel phosphate nanoparticles modified carbon past electrode. Anal. Bioanal. Electrochem. 2011, 3, 134-145.

34. Sakudo, A.; Onodera, T. Virus capture using anionic polymer-coated magnetic beads (review). Int. J. Mol. Med. 2012, 30, 3. [CrossRef] [PubMed]

35. Marszałł, M.P.; Buciński, A. A protein-coated magnetic beads as a tool for the rapid drug-protein binding study. J. Pharm. Biomed. Anal. 2010, 52, 420-424. [CrossRef] [PubMed]

36. Laschi, S.; Miranda-Castro, R.; Gonzalez-Fernandez, E.; Palchetti, I.; Reymond, F.; Rossier, J.S.; Marrazza, G. A new gravity-driven microfluidic-based electrochemical assay coupled to magnetic beads for nucleic acid detection. Electrophoresis 2010, 31, 3727-3736. [CrossRef] [PubMed]

37. Barizuddin, S.; Balakrishnan, B.; Stringer, R.C.; Dweik, M. Highly specific and rapid immuno-fluorescent visualization and detection of E. coli O104: H4 with protein-A coated magnetic beads based LST-MUG assay. J. Microbiol. Methods 2015, 115, 27-33. [CrossRef] [PubMed]

38. Kay, B.K.; Thai, S.; Volgina, V.V. High-throughput biotinylation of proteins. Methods Mol. Biol. 2009, 498, 185-198. [PubMed]

39. Heineman, W.R.; Halsall, H.B. Strategies for electrochemical immunoassay. Anal. Chem. 1985, 57, 1321A-1331A. [CrossRef] [PubMed]

40. Florea, A.; Ravalli, A.; Cristea, C.; Sandulescu, R.; Marrazza, G. An Optimized Bioassay for Mucin1 Detection in Serum Samples. Electroanalysis 2015, 27, 1594-1601. [CrossRef]

41. Ferrara, N.; Gerber, H.-P.; LeCouter, J. The biology of VEGF and its receptors. Nat. Med. 2003, 9, 669-676. [CrossRef] [PubMed]

(C) 2016 by the authors; licensee MDPI, Basel, Switzerland. This article is an open access article distributed under the terms and conditions of the Creative Commons Attribution (CC-BY) license (http://creativecommons.org/licenses/by/4.0/). 